\title{
Experimental Evidence Against Pyrrhonism: Attacking a Straw Man
}

\author{
Diego E. Machuca (ii) \\ CONICET, Buenos Aires, Argentina \\ Corresponding author. E-mail: diegomachuca@conicet.gov.ar.
}

\begin{abstract}
In a recent article, Mario Attie-Picker maintains that a number of experimental studies provide evidence against Sextus Empiricus's empirical claims about both the connection between belief and anxiety and the connection between suspension of judgement and undisturbedness. In this article, I argue that Sextus escapes unharmed from the challenge raised by the studies in question for the simple reason that he does not make the claims ascribed to him. In other words, I argue that Attie-Picker is attacking a straw man.

\section{Résumé}

Dans un article récent, Mario Attie-Picker soutient que plusieurs études expérimentales produisent des preuves contre les affirmations empiriques établies par Sextus Empiricus sur les liens entre, d'une part, la croyance et l'anxiété et, d'autre part, la suspension du jugement et l'imperturbabilité. Dans cet article, je défends l'idée que Sextus sort indemne des objections soulevées par les études en question pour la simple raison qu'il ne fait pas les affirmations qui lui sont attribuées. En d'autres termes, je soutiens qu'Attie-Picker attaque une position qui lui sert d'épouvantail.
\end{abstract}

Keywords: experimental philosophy; Pyrrhonism; suspension; undisturbedness; evaluative belief; assertion; dogmatism

\section{Introduction}

A Pyrrhonist may find in experimental philosophy grist for his sceptical mill inasmuch as experimental studies that examine people's intuitions about thought experiments reveal that there is disagreement between the intuitions of philosophers and those of laypersons, or between the intuitions of the members of different cultural, linguistic, and socio-economic groups. Since the Pyrrhonist finds himself unable to resolve such disagreements, he feels compelled to suspend judgement about the matters under dispute. He likewise suspends judgement in the face of the metaphilosophical disagreement between experimental and armchair philosophers about the correct method of philosophical inquiry because thus far he has been incapable of finding a non-question-begging way of adjudicating that disagreement. Despite his suspending judgement about this second-order dispute, it is perhaps legitimate to presume that it 
would be unwelcome news for the Pyrrhonist if experimental research provided strong evidence against the claims on which his sceptical stance is (allegedly) based. In a recent article, Mario Attie-Picker (2020) purports to show, on the basis of a number of experimental studies, that Sextus Empiricus's claims about both the connection between belief and anxiety and the connection between suspension

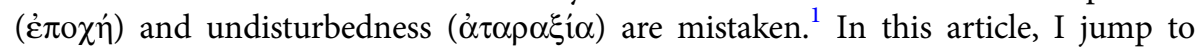
Sextus's defence and argue that Attie-Picker's attempt at refuting Pyrrhonism fails because he drastically misrepresents this brand of scepticism. ${ }^{2}$ In other words, I think that Attie-Picker is attacking a straw man. My motivation in offering the present reply on behalf of Sextus is not (or not merely) an interest in textual exegesis or the historiography of philosophy, but (mainly) an interest in providing an accurate picture of Pyrrhonism understood as a live philosophical option.

In Section 2, I offer a description of the Pyrrhonist's philosophical journey from dogmatism to scepticism for the reader unfamiliar with Sextus's writings. This provides the necessary framework for understanding Attie-Picker's case against Pyrrhonism and my own case against his interpretation of the sceptical stance. In Section 3, I present Attie-Picker's conception of Pyrrhonism and the empirical evidence on the basis of which he purports to show that Sextus got things wrong. In Section 4, I engage with each one of the beliefs and assertions that Attie-Picker erroneously attributes to Sextus, explain the latter's actual stance on several issues, and address an objection to my criticism of Attie-Picker's empirically based argument against Pyrrhonism. In Section 5, I make some concluding remarks.

\section{The Pyrrhonist's Philosophical Journey}

When someone with even a slight familiarity with ancient Pyrrhonism thinks of it, two notions invariably come to mind, namely, suspension and undisturbedness (tranquility, peace of mind). Consider, for instance, Sextus's definition of scepticism:

The sceptical [approach] is an ability to set up oppositions among things that appear and things that are thought in any way whatsoever, an ability from which we come, through the equipollence in the opposed objects and arguments, first to suspension of judgement and after that to undisturbedness. ( $P H$ I 8$)^{3}$

\footnotetext{
${ }^{1}$ Sextus was an ancient Pyrrhonian philosopher and Empirical doctor who lived sometime between the late second century and the early third century $\mathrm{CE}$, and whose surviving writings are our main source for Pyrrhonian scepticism. Two complete works and an important part of a third by Sextus have survived: the three books of Pyrrhonian Outlines, the five extant books of Against the Dogmatists, and the six books of Against the Learned. To refer to Pyrrhonian Outlines, I will use the standard abbreviation PH, which are the

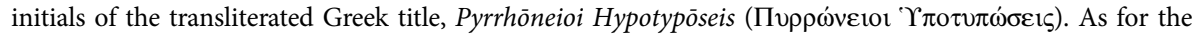
other two works, they are better known by their Latinized titles of Adversus Dogmaticos and Adversus Mathematicos, respectively. Although it is absolutely clear that they are two distinct works, in our manuscripts, Adversus Dogmaticos is attached to the end of Adversus Mathematicos. This has given rise to a deeply entrenched practice of using the title Adversus Mathematicos (AM) VII-XI to refer to the five extant books of Adversus Dogmaticos. Besides the fact that this conventional designation is incorrect, it also creates confusion among non-specialists. For this reason, to refer to Adversus Dogmaticos, I will use the abbreviation $A D$ I-V rather than $A M$ VII-XI.

${ }^{2}$ I will henceforth use 'scepticism' and 'Pyrrhonism,' and their cognates, interchangeably.

${ }^{3}$ All translations of Sextus's texts are mine.
} 
At PH I 10, Sextus defines equipollence or equal strength as "equality in respect of credibility and lack of credibility, so that none of the conflicting arguments takes precedence over any other as more credible" (cf. PH I 190, 196, 202); suspension as "a standstill of the intellect owing to which we neither deny nor affirm anything" (cf. PH I 192, 196); and undisturbedness as "lack of perturbation and calmness of soul." Undisturbedness is not only the mental state at which the Pyrrhonist has arrived after suspending judgement, but the goal that prompted the prospective Pyrrhonist to engage in philosophical investigation in the first place. Sextus tells us that the hope of becoming undisturbed is the "causal principle" (i.e., the initial motivation) of the sceptical philosophy ( $P H$ I 12), and that up to now the Pyrrhonist's aim is both undisturbedness in matters of opinion and moderation of affection in those things that are unavoidable ( $P H$ I 25, 30; cf. $P H$ I 18, 215, III 235). According to Sextus's description of the Pyrrhonist's philosophical journey ( $P H$ I 12, 26, 29; cf. $A M$ I 6), the prospective Pyrrhonist was disturbed by the disagreements or conflicts he found among both perceptual and intellectual appearances and was in a state of aporia regarding which of them he should assent to. For instance, the same object appeared to him to have conflicting perceptual properties depending on different spatial and quantitative variables, or the same moral view appeared to him to be both convincing and unconvincing depending on the vantage point from which it was considered. To remove that state of disturbance, the Pyrrhonist engaged in philosophical inquiry to determine which appearances are true and which are false. He was unable to do this, however, owing to the seeming equipollence of the conflicting appearances, and so he suspended judgement. To his surprise, by suspending judgement, he attained the state of undisturbedness that he was seeking all along - there being thus a contrast between the way undisturbedness was initially expected to be attained and the way it finally happened to be attained. Sextus draws here an analogy between the sceptic and the painter Apelles ( $P H$ I 28), who was painting a horse and trying unsuccessfully to depict the foam around its mouth. In exasperation, he threw the sponge at the canvas, and to his surprise the imprint of the sponge produced the desired representation of the foam. Sextus also remarks that undisturbedness has followed suspension of judgement fortuitously $(P H$ I 26, 29) and as a shadow follows a body (PH I 29).

Sextus does not limit himself to reporting that undisturbedness has in fact closely followed suspension. For in the first and third books of $P H$, and above all in the fifth extant book of $A D$, he also explains why the holding of beliefs about how things really are prevents one from becoming undisturbed, offering at the same time an account of how suspension leads to undisturbedness, as well as to happiness. ${ }^{4}$ His explanation is focused exclusively on beliefs concerning value: the presence of the things one believes to be good and of those one believes to be bad produces perturbation. For when a person lacks what he regards as good, on the one hand, he intensely desires to obtain it and, on the other, he thinks he is persecuted by things naturally bad and restlessly tries to escape from them. If he acquires what he considers to be good, he is

\footnotetext{
${ }^{4}$ The idea that, by becoming undisturbed, the sceptic achieves happiness is not found in $P H$ I and III, but only in $A D$ V. Regardless of their chronological order, perhaps Sextus's experience at the time he wrote $A D$ was different from his experience at the time he wrote $P H$.
} 
nonetheless troubled both because he is irrationally and immoderately exalted and because he is afraid of losing it ( $P H$ I 27, III 237, 277; $A D$ V 116-117, 146). For this reason, even when he is not directly disturbed by the presence of those things he deems to be bad, he continues to be troubled by his constantly guarding against them $(A D \mathrm{~V} 117,129)$. In addition, those who believe that things are by nature good or bad are unhappy or can never attain happiness $(A D \mathrm{~V} 111,113,118,130$, 144 ) inasmuch as "all unhappiness occurs because of some disturbance" ( $A D \mathrm{~V}$ 112, cf. 141). Unlike the belief that things are by nature good or bad, suspension of judgement on the matter makes it possible to attain undisturbedness and happiness ( $P H$ I 28, $A D$ V 111, 144, 160; see also $P H$ III 235, $A D$ V 147, 150, 168). For those who suspend judgement "neither avoid nor pursue anything intensely" ( $P H \mathrm{I}$ 28). Sextus remarks that undisturbedness supervenes upon suspension of judgement about all things ( $P H \mathrm{I}$ 31, 205, $A D \mathrm{~V}$ 144; cf. $A D \mathrm{~V} 160,168$ ), which means that the attainment of undisturbedness has so far occurred only when the sceptic has suspended judgement about all the matters he has investigated - both those that concern values and those that do not.

Despite what Sextus says in some of the passages just referred to, the Pyrrhonist is not free from all disturbance and hence cannot attain complete happiness, since not all disturbance is due to the intense pursuit of the things considered to be good and the intense avoidance of the things considered to be bad. For the Pyrrhonist is disturbed by certain things that impose themselves upon him, such as thirst and hunger ( $P H$ I 29; $A D$ V 143, 148-150, 156-158; cf. PH I 13, 24). Yet he is better off with regard to these unpleasant affections $(\pi \dot{\alpha} \theta \eta)^{5}$ than the dogmatist, since he does not experience the additional disturbance induced by the belief that such affections are by nature bad, and it is precisely the absence of that belief that makes them moderate and more easily borne (PH I 30, III 235-236; $A D$ V 118, 150-155, 161; see also $A D \mathrm{~V}$ $128-129,145,156-160)$. The existence of those involuntary affections is the reason that Sextus says that moderation of affection in things unavoidable is, along with undisturbedness in matters of opinion, the sceptical aim.

\section{Attie-Picker's Conception and Refutation of Pyrrhonism}

Attie-Picker opens his article by claiming that Sextus's Pyrrhonism "presents itself, like most philosophical schools from the Hellenistic period, as offering advice on everyday life" (Attie-Picker, 2020, p. 97, my italics) inasmuch as Sextus takes his Pyrrhonism to have significant practical consequences, the most important of which is that, unlike dogmatism, it makes it possible to attain the state of undisturbedness. What does Sextus understand by 'dogmatism'? For him, a dogmatist is roughly someone who holds beliefs or makes assertions about how things really are or about non-evident matters, especially on the basis of what he regards as sound

\footnotetext{
${ }^{5} \mathrm{~A} \pi \dot{\alpha} \theta 0 \mathrm{o}$ is that which happens to someone or something as a result of being affected by an agent in the broad sense of this term. It refers to the physical and/or psychological state or condition in which the affected person or thing is. Even though in modern ordinary English 'affection' does not have that meaning anymore, I choose that term to render $\pi \dot{\alpha} \theta 0 \varsigma$ for two reasons: not only has 'affection' become in the specialist literature a technical term to translate $\pi \dot{\alpha} \theta$ os, but it also has the advantage of making clear the connection between $\pi \dot{\alpha} \theta 0 \varsigma$ and its cognate verb $\pi \alpha \dot{\sigma} \sigma \varepsilon \mathrm{\varepsilon v}$ ('to be affected').
} 
arguments and objective evidence. Sextus takes the attitudes of arrogance, rashness, and self-satisfaction as characteristic of dogmatism (PH I 20, 62, 90, 177, 212, II 21 , III $2,235,280-281$ ): dogmatists hold fast to their views on $p$ without taking careful account of rival views on $p$ or even despite acknowledging the existence of widespread and entrenched disagreement over $p .{ }^{6}$ Now, Attie-Picker maintains:

At the core of Sextus's project is the thesis that belief itself, independently of any action resulting from it, creates anxiety. As we shall see, the plausibility and success of Pyrrhonism depend on the veracity of this claim. The crucial point to note is that Sextus's thesis is an empirical claim about human psychology. In other words, Sextus's assertion that belief causes anxiety is a claim about our affective reaction to a specific mental state, namely the state of believing a proposition to be true or false. As an empirical hypothesis it is in principle falsifiable, and so it is subject to empirical investigation. (Attie-Picker, 2020, p. 97, my italics)

Attie-Picker also remarks that Sextus's "empirical predictions" (Attie-Picker, 2020, p. 97, my italics) concerning the relationship between belief and anxiety play a central role in the rest of his philosophy. He further claims:

The Pyrrhonian project is thus built upon the empirical observation that suspension of judgment regularly — in fact invariably ("as a shadow follows a body") - brings about tranquility. The Apelles story ( $P H$ 1.28-9) is presented as the accidental discovery of this fact about human psychology. Once the Skeptic experiences this process and its result (ataraxia), he devises a system that enables him to consistently reach the desired mental state. Sextus defines his philosophy as the continual reenactment of this procedure - the creation of opposing arguments of equal force - with the explicit end of becoming tranquil ( $P H$ 1.8-10). (Attie-Picker, 2020, pp. 100-101, my italics)

Attie-Picker purports to falsify or rebut the theses, claims, assertions, and predictions he ascribes to Sextus both by appealing to experimental research conducted by others on the connection between dogmatism and anxiety, and by conducting himself three experimental studies that examine whether scepticism is conducive to undisturbedness.

With regard to the psychological studies on the relationship between dogmatism and anxiety, Attie-Picker first reasonably asks whether what Sextus understands by 'dogmatism' is the same as what this term designates in those studies. He concludes that, although there are important differences, there is enough similarity for the empirical research he reviews to be relevant to the assessment of the Pyrrhonian claim that dogmatism causes anxiety. Although I think that his characterization of the Pyrrhonian conception of dogmatism is incomplete, I agree that the concept of dogmatism as understood in the research in question is close enough to the concept

\footnotetext{
${ }^{6}$ I should note that this is my, not Attie-Picker's, characterization of dogmatism as understood by Sextus.
} 
of dogmatism as understood by Sextus. Be that as it may, my line of attack in the next section will focus on Attie-Picker's characterization of Pyrrhonism.

Attie-Picker remarks that "there seems to be a consensus among psychologists that dogmatism, and overlapping phenomena like system-justification, serves the psychological need to cope with anxiety by protecting the person against perceptions of uncertainty and threat" (Attie-Picker, 2020, p. 107), and that while "Sextus presents his Skepticism as a therapeutic practice capable of alleviating the anxiety resulting from the beliefs of the Dogmatists," the "existing research proposes that it is dogmatism, as opposed to open-mindedness, that has an anxiety-reducing effect" (Attie-Picker, 2020, p. 107).

As for the three experimental studies that Attie-Picker conducted, the first study showed that "higher levels of dogmatism predict lower levels of trait anxiety. Further, higher scores in Dogmatic moral statements ... are also inversely correlated with anxiety. The results are the exact opposite of Sextus's claims" (Attie-Picker, 2020, p. 109). Since the results of the first study were merely correlational, the second study was designed to examine the causal relation between dogmatism and anxiety. Attie-Picker points out that, according to Sextus's "theory on the relationship between anxiety and belief" (Attie-Picker, 2020, p. 111, my italics), "belief in objective moral values invariably leads to anxiety" (Attie-Picker, 2020, p. 112, my italics). Hence, the idea of the second study

was to test if people who were told "by science" that we know the factors that determine happiness ... would exhibit higher levels of state anxiety than people who, like the Pyrrhonian, hear that "science" is in a state of suspension - that we do not know about such factors. The success of the design hinged on whether participants believed, and internalized, what the article claimed. That is, we manipulated scientific claims about our current knowledge regarding what is good, but we hoped to indirectly manipulate the subjects' certainty about their own beliefs. The manipulation check suggested that this was indeed the case. This, however, had absolutely no effect on state anxiety score. The results thus failed to find any evidence supporting Sextus's claims. (Attie-Picker, 2020, pp. 111-112)

The third study tested whether people with stronger moral views are more anxious than people who express less certainty in their moral views. The results failed to support Sextus's hypothesis that moral belief causes anxiety. Attie-Picker remarks that the results of the three studies "did not provide any evidence for Sextus's anxiety claim. ... While the results are far from conclusive, they strongly suggest that the relationship between dogmatism and anxiety is the opposite of what Sextus claimed" (Attie-Picker, 2020, p. 118).

Attie-Picker considers two objections to his three studies. The first is that all the participants in those studies retain some belief about what is good, which means that according to Sextus they will not be able to attain undisturbedness inasmuch this state of mind follows from total suspension of judgement. In reply, Attie-Picker observes that the objection in question "entails the view that tranquility cannot increase incrementally as the would-be Skeptic (or anyone else) loses the 
appropriate beliefs," whereas Sextus "explicitly endorses the idea that tranquility follows from gradual changes in belief" (Attie-Picker, 2020, p. 119). He adds:

Presumably, the first time the Skeptic suspends judgment, she does not suspend judgment about everything. Rather, just as Apelles was painting a particular painting (a horse), the Skeptic was investigating a particular problem. When she suspends judgment about that problem, Sextus tells us, she discovers that suspension is followed by tranquility. She then proceeds to apply the Pyrrhonian method to all problems. The whole project would not have been possible if the initial discovery had not produced tranquility. Thus, it is not necessary to suspend judgment about everything to obtain the benefit of abandoning some beliefs. This is especially clear in the last chapter of the Outlines. Sextus writes, "Sceptics are philanthropic and wish to cure by argument, as far as they can, the conceit and rashness of the Dogmatists" ( $P H 3.280$, emphasis mine). (Attie-Picker, 2020, p. 119)

The second objection is that the participants in the second study do not actually suspend judgement about whether anything is really good, bad, or indifferent inasmuch as they believe that happiness is good but do not know how to obtain it. Thus, the participants do not "become more skeptical with respect to the belief that really matters, i.e., that happiness is good. A Pyrrhonist, Sextus might say, becomes tranquil not merely by suspending judgment about what brings about happiness, but rather by suspending judgment about the value of happiness itself" (Attie-Picker, 2020, p. 120). In reply, Attie-Picker remarks:

there is an important way in which the Skeptic's situation parallels that of the participants: just as the latter do not question the belief that happiness is good, the Skeptic never questions the claim that tranquility is the goal of human life. Consider what would happen if Sextus suspended judgment about whether tranquility is the end. What reason would he then have to keep devising a contrary account to every account? Questioning that "for the sake of which everything is done or considered" ( $P H$ 1.25) puts into question the very purpose of being a Skeptic.

... Therefore, just like the participants, the Skeptic does not suspend judgment about the goal (happiness for the former, tranquility for the latter). In both cases, the goal is fixed. Thus, in an important sense, the fact (if it is a fact) that the participants do not suspend judgment about whether happiness is good is not enough to invalidate the results. Furthermore, at key passages Sextus seems to equate ataraxia with eudaimonia (happiness). ... In light of these passages, it is fair to conclude that the Skeptic, like the participants, does not question the value of happiness. (Attie-Picker, 2020, pp. 120-121)

I think that, in his refutation of Sextan Pyrrhonism, Attie-Picker is actually arguing against a straw man because he drastically misrepresents several crucial aspects of that sceptical stance, as I propose to show in the next section. 


\section{Sextus's Actual Stance}

It should first of all be observed that the qualms voiced by Attie-Picker concerning the plausibility of Sextus's remarks about both the connection between belief and anxiety or disturbance and that between suspension and undisturbedness are common among readers of Sextus. In fact, several specialists in ancient Pyrrhonism have contested the practical value of both suspension and undisturbedness. For instance, it has been argued that most theoretical puzzles, difficulties, or disagreements do not cause anxiety but are instead exciting and enthralling (Barnes, 2000, pp. $\mathrm{xxx}-\mathrm{xxxi}$; Mates, 1996, pp. 63, 75-76); that it is unreasonable or ridiculous to think that suspension can eliminate or mitigate the anxiety a person experiences or that suspension is a reliable recipe for undisturbedness (Barnes, 2000, p. xxxi; Bett, 2019, p. 172; Mates, 1996, pp. 63, 76-77); that belief in objective values produces a sense of security, not anxiety (Annas, 1998, pp. 208, 213); that belief about what is good or bad, or what is true or false, is what gives meaning and sense to one's life (Burnyeat, 1997, p. 46); and that it is highly doubtful that the attainment of undisturbedness is either desirable or psychologically possible (Striker, 2004, p. 22, 2010, p. 196). If any of this were true, then the practical value of suspension and undisturbedness would be undermined. For in those cases in which unresolved disagreements do not cause anxiety, there is nothing to be removed through suspension, while in those cases in which there is indeed anxiety concerning matters of belief, suspension is useless either because it is not efficacious in removing that anxiety or because it is impossible to achieve that goal given human beings' psychological constitution. And even if it were psychologically possible to attain undisturbedness by suspending judgement, living an undisturbed life is not appealing or desirable because it would deprive us of all excitement or all meaning. Although Attie-Picker does not cite any of the scholarly works just referred to, I take it that he was as astonished as their authors by Sextus's remarks about both the connection between belief and disturbance and the connection between suspension and undisturbedness, the reason being that these remarks do not correspond to his own experience and the experience of those with whom he is acquainted. And I take it that it was such astonishment that led him to undertake experimental studies to put Sextus's remarks to the test. I have elsewhere responded to the abovementioned specialists (Machuca, 2006, p. 124, 2019c, pp. 49-51; see also McPherran, 1989, pp. 150, 171). My reply to Attie-Picker requires somewhat different comments.

As we saw in the previous section, the first thing that Attie-Picker says about Pyrrhonism is that it offers advice. At least in the present context, the notion of advice is clearly normative or prescriptive inasmuch as, in offering advice, the Pyrrhonist recommends that a given course of action (suspending judgement) be undertaken because it will enable us to attain something that is good, namely, undisturbedness. Similarly, he recommends that another course of action (holding beliefs) not be undertaken because it will produce something that is bad, namely, anxiety or disturbance. Thus, the Pyrrhonist claims that suspension should be preferred over the holding of beliefs because he makes evaluative judgements about the states of undisturbedness and anxiety, judgements that result in his holding beliefs about the objective value of those states. Now, the problem with saying that the 
Pyrrhonist offers advice is that he does not make normative claims because he refrains from making any kind of evaluative judgement. For this reason, it is a flagrant mistake to say that the Pyrrhonist does not suspend judgement about whether undisturbedness and happiness are good or that he does not question their value. If he did hold beliefs about the value of undisturbedness and happiness, he would be holding the very same kind of evaluative belief that is held by dogmatists and that has so far been followed by mental disturbance. Note that this last remark is not to be understood as expressing a belief about the causal connection between belief and disturbance: pace Attie-Picker, the Pyrrhonist refrains from endorsing any theory whatsoever, and from making any assertion, about whether belief invariably causes anxiety. He likewise refrains from maintaining that there is a causal relationship between suspension and undisturbedness, or that the former invariably brings about the latter. The Pyrrhonist limits himself to reporting on what he has so far observed and abstains from making any claim that goes beyond the realm of his own appearances. The image of a shadow following a body ( $P H$ I 29) can indeed be understood as indicating an invariable connection between suspension and undisturbedness inasmuch as a shadow always and necessarily follows a body when the body blocks light. But note that, to compare the way undisturbedness follows the person who suspends judgement with the way a shadow follows a body, Sextus employs the verb $\pi \alpha \rho \alpha \kappa о \lambda о v \theta \varepsilon i v$ ( $P H$ I 29, also 26), which not merely means 'to follow,' but 'to follow closely.' By my lights, this indicates that Sextus wants to lay emphasis on the fact that there is a close connection between suspension and undisturbedness as there is between a body and its shadow, rather than to express the belief that suspension invariably causes undisturbedness. More precisely, his intention is to indicate that at least up to now the Pyrrhonist's suspension has been closely accompanied by undisturbedness (cf. Machuca, 2006, p. 116). In sum, while Attie-Picker's account of Sextus's stance ascribes to the Pyrrhonist a number of beliefs or assertions about the nature of things or the causal connection between certain mental states, the Pyrrhonist actually suspends those beliefs and refrains from making those assertions. ${ }^{7}$ If that is so, then the experimental studies that, according to Attie-Picker, provide evidence that such beliefs and assertions are false or unjustified do nothing to undermine the Pyrrhonist's stance.

With regard to undisturbedness, it should also be observed that, contrary to what Attie-Picker maintains in his reply to the second of the two objections he considers, Sextus neither regards the goal of undisturbedness as fixed nor believes that one cannot question the claim that undisturbedness is the goal of human life. As I have argued elsewhere (Machuca, 2006, 2020), in four passages Sextus makes it clear that neither the pursuit nor the attainment of undisturbedness are essential to Pyrrhonism ( $P H$ I 12, 25, 232, and $A M$ I 6). Since this is not the place to examine

\footnotetext{
${ }^{7}$ There is among interpreters a vigorous debate about the scope of Pyrrhonian suspension, namely, whether it is limited to theoretical or philosophico-scientific beliefs or else encompasses also ordinary or everyday beliefs (see especially the five essays collected in Burnyeat \& Frede, 1997). I side with those who take Pyrrhonian suspension to be all-embracing. But even if one accepts the view that it is limited to theoretical beliefs, these are the kind of beliefs that Attie-Picker ascribes to the Pyrrhonist, and so even those interpreters who defend that view will oppose Attie-Picker's description of the Pyrrhonian stance.
} 
all of these passages, let me briefly focus on one of them. At PH I 25, Sextus tells us: "We say up to now that the sceptic's aim is undisturbedness in matters of opinion and moderation of affection in things unavoidable." The reason that the sceptic says up to now that part of his aim is undisturbedness in matters of opinion is that this mental state has thus far appeared to him to be so, and that he does not rule out the possibility that he might say otherwise in the future because things might appear differently to him in the future. Up to now, the sceptic has desired to attain undisturbedness, and so has searched for it, but he does not exclude the possibility that, in the future, he might pursue a different aim. Sextus is therefore recognizing that undisturbedness might cease to appear to the sceptic as a state of mind worth experiencing. If this interpretation is correct, then the sceptic refrains from endorsing the view that undisturbedness is the fixed goal of human life.

If the Pyrrhonist suspends judgement about the objective value of undisturbedness and does not consider it to be essential to his stance, then a problem seems to arise: as Attie-Picker remarks, the Pyrrhonist would lack a reason to (continue to) produce oppositions between claims or arguments. But this problem is merely apparent. Note, first, that if the Pyrrhonist's pursuit of undisturbedness is to be explained as a mere preference shaped by circumstantial factors such as his socio-cultural milieu rather than as the result of his believing that it is objectively good, that would be enough reason for him to continue to produce the above oppositions with the nondoxastic expectation that what has happened until now might continue to happen in the future. Second, the Pyrrhonist has an interest in the inquiry into truth that is independent of his interest in undisturbedness (Machuca, 2011b, pp. 252-253, 2013, Section 2, 2019a, pp. 208-218; Perin, 2010, Chapter 1). His main way of undertaking his philosophical inquiries is by producing oppositions among claims or arguments with the aim of assessing their epistemic credentials. Thus, even if he abandoned his desire for undisturbedness, he would still have a reason for producing such oppositions. It is therefore not the case, pace Attie-Picker, that the sceptic's "whole project would not have been possible if the initial discovery had not produced tranquility" (Attie-Picker, 2020, p. 119). ${ }^{8}$

The previous remark brings me to Attie-Picker's reply to the first of the two objections he considers, a reply that calls for several comments. To begin with, the view that the attainment of undisturbedness does not require suspending judgement across the board was already defended by Jonathan Barnes (1990) - whom, incidentally, Attie-Picker does not cite. According to Barnes: "A man who suffers only mildly from $\tau \alpha \rho \alpha \chi \eta \dot{~ m a y ~ b e ~ a ~ p e r f e c t ~ P y r r h o n i s t ; ~ f o r ~ h e ~ m a y ~ a c h i e v e ~ c o m p l e t e ~} \dot{\alpha} \tau \alpha \rho \alpha \xi \dot{i} \alpha$

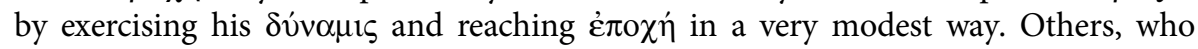
find the whole of life a sea of troubles, will not be set at rest until they have achieved

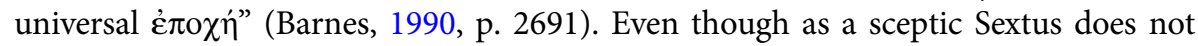
rule out the possibility that others will attain undisturbedness by suspending judgement only about some beliefs, given his past experience it appears to him that

\footnotetext{
${ }^{8}$ As we saw in the previous section, where I cited the longer passage to which this quote belongs, Attie-Picker states that the discovery in question is that suspension is followed by undisturbedness. But it is nonsensical to say that the Pyrrhonist becomes undisturbed by discovering that he became undisturbed after suspending judgement.
} 
undisturbedness will be attained only when judgement is suspended across the board. As we saw in Section 2, he explicitly remarks that unperturbedness supervenes upon

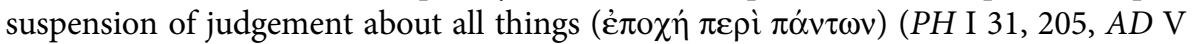
144; cf. $A D \mathrm{~V} \mathrm{160,168).} \mathrm{I} \mathrm{take} \mathrm{this} \mathrm{to} \mathrm{mean} \mathrm{that} \mathrm{attainment} \mathrm{of} \mathrm{undisturbedness} \mathrm{has} \mathrm{at}$ least thus far occurred only when the Pyrrhonist has suspended judgement about all the matters into which he has inquired. Of course, all the matters into which he has so far inquired are not all the matters into which he may inquire. But it is plain that the sceptic did not become undisturbed the first time he suspended judgement about a particular problem. Moreover, to the best of my knowledge, nowhere does Sextus explicitly endorse the view that undisturbedness follows from gradual changes in belief. Why did the sceptic not attain undisturbedness after the first time he suspended judgement about a particular issue? The reason seems to be that he still held evaluative beliefs - including the belief that discovering the truth about the matters under investigation is of objective value - and that it is the holding of evaluative beliefs that is the ultimate source of doxastic disturbance (Machuca, 2019b). If this is so, then, first, there is indeed a crucial difference between the participants in Attie-Picker's experimental studies and the sceptics: whereas the former still hold evaluative beliefs, the latter hold no evaluative beliefs whatsoever - not even, as argued above, about undisturbedness and happiness. Second, Sextus should have said that undisturbedness follows upon suspension about all evaluative matters rather than about all matters tout court. Let me explain. The sceptic does suspend judgement about all the matters he has so far investigated - both evaluative and non-evaluative - because the conflicting views on those matters strike him as equally persuasive or credible. But if my interpretation is on the right track, then the sceptic could attain undisturbedness if he suspended judgement about all evaluative matters while holding beliefs about non-evaluative matters. In that case, he would of course cease to be a sceptic, but he could still become undisturbed (for a detailed discussion of this issue, see Machuca, 2019b, pp. 207-209, 212).

Given that Attie-Picker mentions PH III 280 in support of his view that the sceptic attainted undisturbedness after the first time he suspended judgement about a particular matter, let me say something about this passage. When Sextus remarks that the sceptical doctor cures his dogmatic patients' conceit and rashness as far as he can, he is not referring to the number of beliefs about which he or his patients suspend judgement. Rather, he is expressing the sceptic's characteristic humility and caution: he refrains from affirming that his argumentative therapy has worked on every occasion and from assuring us that it will be efficacious in every, or even any, future patient afflicted by conceit and rashness. Sextus recognizes that the sceptic's arguments have failed, and will perhaps fail, to induce certain people to abandon their beliefs and suspend judgement; he does not even believe (or disbelieve) that there is always an argument that is capable of inducing suspension (Machuca, 2009, pp. 107-108, 2019a, pp. 204-205). Now, given Sextus's caution regarding what might or might not happen in the future, I disagree both with Attie-Picker's claim that the sceptic makes empirical predictions and with his claim that the sceptic has devised a system that enables him to consistently attain undisturbedness. The sceptic expects that one event will follow another, but this is merely a non-doxastic expectation that is triggered by the memory of his past experience, in much the same way as the observation 
of smoke, in conjunction with the past observation of smoke and fire together, immediately brings to mind the idea of fire ( $P H$ II 101-102, $A D$ II 152, 157).

If my interpretation of Sextus's Pyrrhonism is on the right track, then he does not propose any thesis that describes a fact about human psychology that he has accidentally discovered. If he did, then his philosophical inquiries would have enabled him to find (even if by chance) an important truth. But he explicitly remarks that, while the dogmatists claim to have discovered the truth about the matters under investigation, the sceptics continue to inquire because they have not yet found any answers (PH I 13, II 11). Hence, when Sextus talks about the connection between suspension and undisturbedness as well as that between belief and disturbance, he is not to be interpreted as proposing a theory about human psychology, but as providing information about his own personal experience or as making autobiographical remarks.

It is important to emphasize that, if Sextus made all the sorts of claims or assertions that Attie-Picker ascribes to him, he would be a sitting duck for his dogmatic rivals, who would at once accuse him of blatant inconsistency: he would be making the very same sort of claim or assertion about how things really that is the target of his Pyrrhonian onslaught. Sextus explicitly and repeatedly points out that the sceptic refrains from making assertions about, e.g., the external objects, the matters under investigation, or the sceptical phrases, limiting himself instead to reporting on what appears to him at the moment (e.g., PH I 4, 15, 35, 191, 195-196, 200, 206; $A D$ II 474). So unless we take Sextus and his fellow Pyrrhonists to be but the most simple-minded philosophers - despite having devised sophisticated argumentative weapons that still today are taken to pose serious epistemological challenges that deserve in-depth analysis - one had better ask oneself if one has not made a gross mistake in one's interpretation of their sceptical stance.

I have not attempted to discredit the results of the experimental research conducted by Attie-Picker and others, but only to make the case that the experimental studies in question do not pose a rebutting defeater for Sextus's Pyrrhonism for the simple reason that he does not make the kind of claims or assertions that Attie-Picker purports to rebut on the basis of those studies. ${ }^{9}$ It should then be

\footnotetext{
${ }^{9}$ It is worth noting here that the Pyrrhonian sceptic that Nichols, Stich, and Weinberg (2003) have in mind is also a straw man. They contend that, contrary to what some epistemologists believe, the intuitions underlying the arguments for Cartesian scepticism are not universal inasmuch as experimental evidence suggests that "many of the intuitions epistemologists invoke vary with the cultural background, socioeconomic status, and educational background of the person offering the intuition" (Nichols et al., 2003, p. 227), and that "the appeal of skeptical arguments is culturally local and that this fact justifies a kind of 'meta-skepticism' since it suggests that crucial premises in the arguments for skepticism are not to be trusted" (Nichols et al., 2003, p. 228). Even though they limit their inquiry to Cartesian scepticism, they observe that the principles underlying the Pyrrhonist's Agrippan trilemma too are supported by intuitions, and that something similar to the argument they put forward against Cartesian scepticism "might at some later date find a Pyrrhonian target" (Nichols et al., 2003, pp. 246-247 n. 4). It should be noted both that the Pyrrhonist would not deny that the trilemma works only within a certain conception of knowledge and justification, and that his arguments are at least to a large extent parasitic on the philosophical doctrines of those against whom he argues. The trilemma's reliance on certain epistemological presuppositions would represent a problem only for those who embrace such presuppositions and who believe that the trilemma poses an insurmountable conundrum for any rational being. By contrast, the Pyrrhonist is not committed to those theoretical presuppositions or to the soundness of the trilemma (Machuca, 2015, Section IV).
} 
clear that the considerations I have made in defence of Sextus are not meant to deny that most people do not, or would not, find solace in the sceptic's suspension of judgement. I myself, despite being sympathetic to Pyrrhonism, find the possibility of becoming undisturbed by suspending judgement as incompatible with my temperament and life experience. However, this does not lead me to affirm that Sextus's remarks about his own and others' experience are insincere or false, the reason being that I am extremely cautious about discarding someone's report on his own experience because it is entirely different from my own or from that of the people I know. Whether a person is disturbed by his holding evaluative beliefs or whether he is able to become undisturbed by suspending judgement seems to depend on his own psychological makeup and personal history. In fact, there are people who claim to have found in Pyrrhonism some sort of mental tranquility. A scholar once told me that the reading of Sextus's writings prompted the experience of "being blissful" in much the same way as did the reading of certain Buddhist texts. Another scholar explained to me that, when he first saw the Ten Oxherding Pictures from the Buddhist tradition, he was moved in a way he could not put into words, and that Pyrrhonism later provided him with those words. Moreover, I was recently contacted by a person who created "The Modern Pyrrhonism Movement" and who wrote a non-academic book on Pyrrhonism in which he explains how modern readers can apply the Pyrrhonian practice - which he regards as strikingly similar to the Buddhist practice - to everyday life to achieve inner peace. Even though all these reported practical benefits of Pyrrhonism are entirely foreign to me, I refrain from affirming that those who claim to enjoy them are disingenuous or confused. Pyrrhonism may or may not work for you as a means to deal with mental anxiety, so the only thing you can do, if you are curious enough, is try and see.

Before concluding, let me consider the following objection. At $A D \mathrm{~V} 140$, Sextus remarks that it is possible to avoid disturbance by teaching that nothing is by nature good or bad, and that since this teaching is peculiar to scepticism, "it belongs to scepticism to procure the happy life." If Sextus does argue that scepticism is uniquely suited to achieve the undisturbed and happy life, then evidence about its efficacy in bringing about such a life is indeed relevant, and it is precisely such evidence that is provided by the experiments reviewed by Attie-Picker. I will set aside here the problem posed by the fact that claiming that the sceptic teaches that nothing is by nature good or bad is at variance with his professed suspension of judgement because it is not relevant to the purposes of the present article. ${ }^{10}$ Regarding the question of whether scepticism is an efficacious means to attain undisturbedness and happiness, I think that Sextus's remarks expounded in Section 2 should be understood both as a non-committal report of his own experience and as a dialectical manoeuvre. First, it appears to him that up to this point scepticism has made it possible for him and others to attain undisturbedness, and that becoming undisturbed is central to being happy. But Sextus does not - and this point is crucial - use his own

\footnotetext{
${ }^{10}$ There is a scholarly debate about whether the sceptical stance expounded in $A D \mathrm{~V}$ is different from that expounded in PH (see, e.g., Bett, 1997; Machuca, 2011a). The main point of contention is precisely whether in $A D \mathrm{~V}$ the sceptic does not suspend judgement about whether anything is good or bad by nature, but rather denies that anything is such.
} 
experience as the basis on which he asserts that scepticism is the only way to secure an undisturbed and happy life. Second, two of his main dogmatic rivals, namely, the Stoics and the Epicureans, regarded undisturbedness as the principal component of happiness, or at least as an important component thereof (Bett, 1997, p. 144; McPherran, 1989, p. 138; Striker, 1996, pp. 185-188). Sextus may then be putting forward a dialectical argument with the aim of countering his rivals' arguments to the effect that only by endorsing certain philosophical tenets can one achieve undisturbedness and happiness. In light of these two points, one may say that Sextus does not actually assert that scepticism is the only efficacious strategy - or at least one efficacious strategy - for securing undisturbedness and happiness. It could be argued, though, that even if we regard Sextus's remark that Pyrrhonism makes it possible to lead an undisturbed and happy life as a mere report of his own appearances, what matters here is not whether he would be refuted by the experimental evidence presented by Attie-Picker - given that one cannot refute someone who does not make assertions - but whether we should take his appearances seriously as guides to the way we should live. Gathering evidence that Sextus's experience is not representative - inasmuch as many do not share it - is relevant in deciding whether we should follow his way of life. I agree that the experimental evidence in question might be useful to those who are considering whether the sceptical stance might help them alleviate the distress they are suffering. But we must bear in mind a point I made at the beginning of the present section: when reporting on his own past experience, Sextus is not making normative claims, i.e., he is not telling us how we should live or that we should follow his way of life. Rather, he is merely issuing autobiographical reports of how he is affected for his readers to consider. For this reason, providing evidence that others do not think they should adopt the sceptical approach does not represent a real challenge to him. ${ }^{11}$

\section{Concluding Remarks}

It goes without saying that, when attempting to refute a philosopher's stance, one had better do one's best not to distort it. Otherwise, one ends up arguing against a straw man. In this article, I have argued that this is what happens with Attie-Picker's attempt at rebutting Sextus's remarks about both the connection between belief and anxiety and the connection between suspension and undisturbedness. For Sextus does not hold beliefs or make assertions about the objective value of undisturbedness and happiness, or about the causal relationship between suspension and

\footnotetext{
${ }^{11}$ The same misunderstanding of Sextus's stance shown by Attie-Picker is found in Dimech (forthcoming), who offers reasons against the interpretation of Hume as a Pyrrhonian sceptic. The main reason is Hume's critique of the connection between suspension and undisturbedness, a critique that Dimech finds persuasive and of philosophical value. For Hume shows, according to Dimech, that Sextus's "view" that across-the-board suspension is "the unique path to tranquillity" is mistaken inasmuch as such a state of suspension can only lead to "a miserable existence," does not have "pleasant psychological effects," and undermine our "basic psychological stability." Incidentally, Dimech also ascribes to Sextus the view that "we can never hold one particular belief or appearance to be more veridical than not" and the view that the Pyrrhonist shuns or condemns "all 'philosophical investigations' into the true natures of things." However, as noted above, the Pyrrhonist is engaged in philosophical inquiry into truth and, given his open-mindedness, he does not rule out the possibility of eventually discovering that a given belief or appearance is to be preferred to others as more veridical.
} 
undisturbedness or between belief and anxiety. Neither does he propose a theory about the human mind, make predictions about his argumentative therapy, or tell us how we should live. If Sextus had done any of that, then the results of the experimental studies appealed to by Attie-Picker might be taken to provide a rebutting defeater for Pyrrhonism. But Sextus only limits himself instead to reporting on his own, and others', experience, which seems to be also that of a number of present-day individuals who have found in the Pyrrhonian stance an efficacious way of coping with their own anxiety.

Acknowledgements. I am grateful to two anonymous reviewers for their comments on a previous version of this article, and to Jill Flohil for her careful copyediting.

\section{References}

Annas, J. (1998). Doing without objective values: Ancient and modern strategies. In S. Everson (Ed.), Companions to Ancient thought IV: Ethics (pp. 193-220). Cambridge University Press.

Attie-Picker, M. (2020). Does skepticism lead to tranquillity? Exploring a Pyrrhonian theme. In T. Lombrozo, J. Knobe, \& S. Nichols (Eds.), Oxford studies in experimental philosophy Volume 3 (pp. 97-125). Oxford University Press.

Barnes, J. (1990). Pyrrhonism, belief and causation: Observations on the scepticism of Sextus Empiricus. In W. Haase (Ed.), Aufstieg und Niedergang der römischen Welt II 36.4 (pp. 2608-2695). De Gruyter.

Barnes, J. (2000). Introduction. In J. Annas \& J. Barnes (Trans.), Sextus Empiricus: Outlines of scepticism, $2^{\text {nd }}$ edition (pp. xi-xxxi). Cambridge University Press.

Bett, R. (Trans.). (1997). Sextus Empiricus: Against the ethicists. Clarendon Press.

Bett, R. (2019). Le scepticisme ancien est-il viable aujourd'hui? In D. Machuca \& S. Marchand (Eds.), Les raisons du doute: études sur le scepticisme antique (pp. 153-177). Classiques Garnier.

Burnyeat, M. (1997). Can the sceptic live his scepticism? In M. Burnyeat \& M. Frede (Eds.), The original sceptics: A controversy (pp. 25-57). Hackett.

Burnyeat, M., \& Frede, M. (Eds.). (1997). The original sceptics: A controversy. Hackett.

Dimech, D. K. Forthcoming. Hume is the enemy of Pyrrho. Philosophy. https://doi.org/10.1017/ S0031819121000188

Machuca, D. (2006). The Pyrrhonist's $\alpha \tau \alpha \rho \alpha \xi i \alpha$ and $\varphi 1 \lambda \alpha v \theta \rho \omega \pi i \alpha$. Ancient Philosophy, 26(1), 111-139.

Machuca, D. (2009). Argumentative persuasiveness in ancient Pyrrhonism. Méthexis, 22, 101-126.

Machuca, D. (2011a). Moderate ethical realism in Sextus' Against the Ethicists? In D. Machuca (Ed.), New essays on Ancient Pyrrhonism (pp. 143-178). Brill.

Machuca, D. (2011b). Ancient skepticism: Pyrrhonism. Philosophy Compass, 6(4), 246-258.

Machuca, D. (2013). Pyrrhonism, inquiry, and rationality. Elenchos, 34(1), 201-228.

Machuca, D. (2015). Agrippan Pyrrhonism and the challenge of disagreement. Journal of Philosophical Research, 40, 23-39.

Machuca, D. (2019a). Pyrrhonian argumentation: Therapy, dialectic, and inquiry. Apeiron, 52(2), 199-221.

Machuca, D. (2019b). Sources of doxastic disturbance in Sextus Empiricus. Oxford Studies in Ancient Philosophy, 56, 193-214.

Machuca, D. (2019c). Does Pyrrhonism have practical or epistemic value? In G. Veltri, R. Haliva, S. Schmid, \& E. Spinelli (Eds.), Sceptical paths (pp. 43-66). De Gruyter.

Machuca, D. (2020). Sextus on ataraxia revisited. Ancient Philosophy, 40(2), 435-452.

Mates, B. (Trans.). (1996). The skeptic way: Sextus Empiricus's Outlines of Pyrrhonism. Oxford University Press.

McPherran, M. (1989). Ataraxia and Eudaimonia in Ancient Pyrrhonism: Is the skeptic really happy? Proceedings of the Boston Area Colloquium in Ancient Philosophy, 5(1), 135-171.

Nichols, S., Stich, S., \& Weinberg, J. (2003). Meta-skepticism: Meditations in ethno-epistemology. In S. Luper (Ed.), The skeptics: Contemporary essays (pp. 227-247). Ashgate.

Perin, C. (2010). The demands of reason: An essay on Pyrrhonian scepticism. Oxford University Press. 
Striker, G. (1996). Ataraxia: Happiness as tranquillity. In G. Striker (Ed.), Essays on Hellenistic epistemology and ethics (pp. 183-195). Cambridge University Press.

Striker, G. (2004). Historical reflections on classical Pyrrhonism and neo-Pyrrhonism. In W. Sinnott-Armstrong (Ed.), Pyrrhonian skepticism (pp. 13-24). Oxford University Press.

Striker, G. (2010). Academics versus Pyrrhonists, reconsidered. In R. Bett (Ed.), The Cambridge companion to ancient scepticism (pp. 195-207). Cambridge University Press.

Cite this article: Machuca, D. E. (2022). Experimental Evidence Against Pyrrhonism: Attacking a Straw Man. Dialogue 61(1), 123-138. https://doi.org/10.1017/S0012217321000160 